\title{
EVIDENCE OF COLD SEEPING IN PLIO-PLEISTOCENE SEDIMENTS OF SE PELOPONESE: THE FOSSIL CARBONATE CHIMNEYS OF NEAPOLIS REGION
}

\author{
Sakellariou D. ${ }^{1}$, Fountoulis $I^{2}{ }^{2}$ and Lykousis V. ${ }^{1}$ \\ ${ }^{1}$ Institute of Oceanography, Hellenic Centre for Marine Research, POBox 712, 19013 Anavyssos, Greece, \\ sakell@ath.hcmr.gr,vlikou@ath.hcmr.gr \\ ${ }^{2}$ University of Athens, Faculty of Geology \& Geoenvironment, Dept. Dynamic Tectonic Applied Geology, \\ Panepistimiopolis Zografou, 157 84, Athens, Greece,fountoulis@geol.uoa.gr
}

\begin{abstract}
Unique, upright standing, chimney-like structures outcropping in (Plio-)Pleistocene sediments of Neapolis region, SE Peloponese are studied thoroughly. The up to $5 \mathrm{~m}$ high and $3 \mathrm{~m}$ wide structures, previously interpreted either as "rhizoliths" or hypercalcified giant sponges or fossilized palm trees, display a wide range of morphological types and are composed of hard, several cm thick, carbonate tube. Their orifice is filled up with muddy, sandy or fine conglomerate material, which reflects the sedimentary nature of the surrounding formation, and is penetrated by numerous whitish, mm-thin, carbonate veins. Their formation and spatial occurrence is genetically associated with two intersecting systems of diaclases/fractures, also sealed with carbonate material. We interpret these structures as non-volcanic, fossil, gas chimneys, related to cold seeping (biogenic methane? seeping). The intersecting diaclases have been used as conduits for the upward fluid migration, thus, the gas seeping process must have taken place after the diagenesis of the host sedimentary formations. The impressive outcrops of carbonate gas chimneys in the Neapolis region is the first evident of cold seeping, eventually related with mud volcanism, in the Plio-Pleistocene sedimentary basins of the Hellenic Forearc.
\end{abstract}

Key words: non-volcanic gas chimneys, cold seeping, diaclases/fractures, Hellenic Forearc.

\section{Introduction}

This paper aims at shedding light to the origin and formation of the unique, strange, morphologically positive structures which protrude through the Plio(?)-Pleistocene deposits in the area of Neapolis, in SE Peloponese. The main occurrences are on the coast of Agia Marina and Korakas, south and southeast of Neapolis town, and in the area of Vourlopo, north of the town.

Similar structures, close to Plitra and Elea, have been firstly described by Kowalczyk \& Winter (1991) and interpreted as "rhizoliths" (Osteokollen) filled by cemented conglomerate, which, due to their resistance to the erosion, outcrop today as positive, column-like structures. Little later, Georgiades-Dikeoulia et al. (2000) studied the outcrop of Agia Marina and interpreted them as hypercalcified sponges belonging to the Ischyrospongia (Sclerospongia and Pharetronidae) of the Class Demospongia. In 2005 Prof. E. Velitzelos published an article in the popular magazine Geotropio $(\mathrm{Nr} 287$, Oct.15, 2005) on the petrified forest of Agia Marina. This author interpreted the 


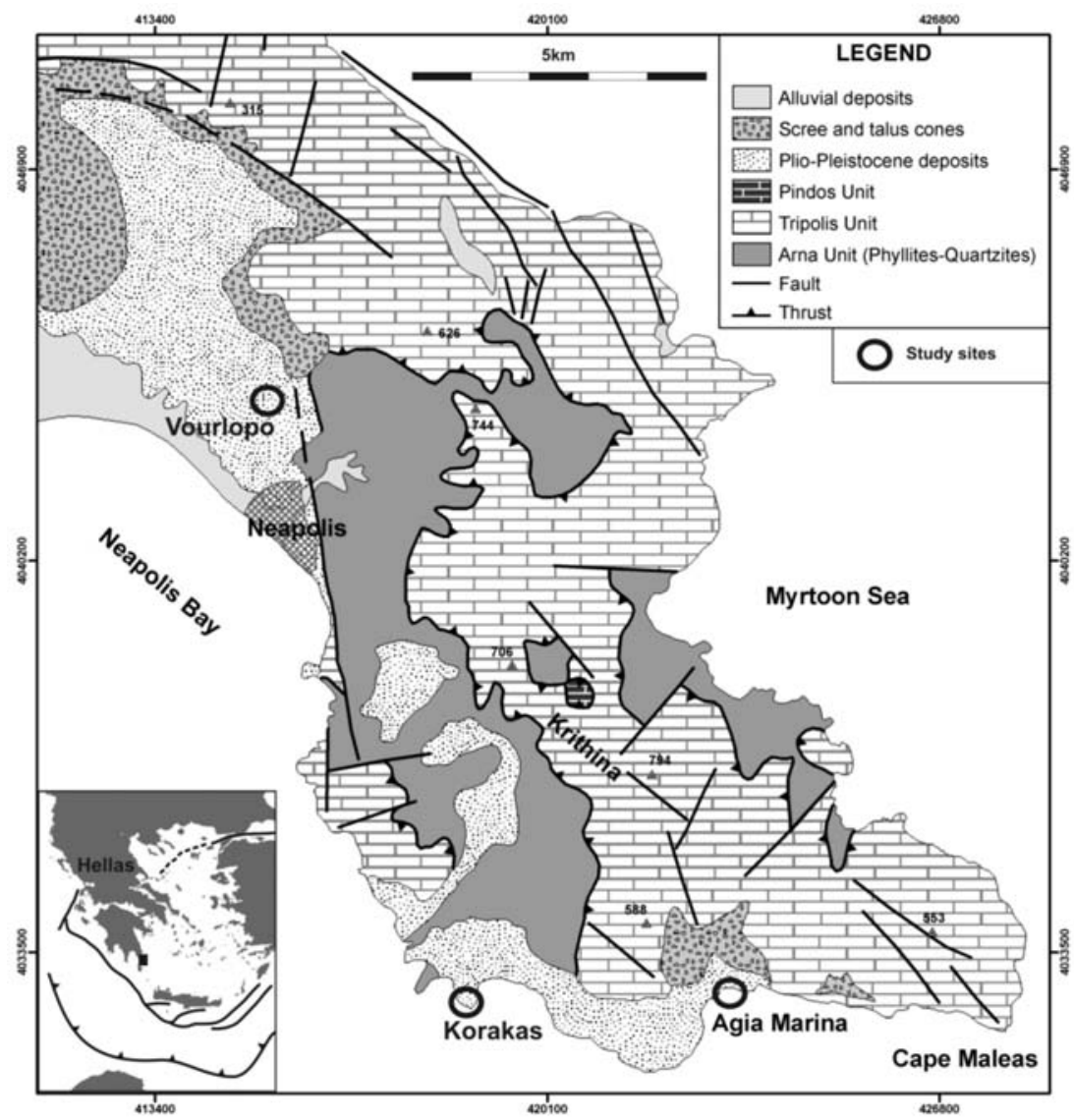

Fig. 1: Simplified geological and neotectonic map of the Neapolis - Maleas Peninsula, modified after Gerolymatos (1999) and Lekkas et al. (1995). The three study sites are marked in open circles.

same structures as in-situ fossilized trees and roots, possibly palm trees, representing the remnants of a petrified forest of Plio-Pleistocene age. In a nicely edited booklet entitled "The Agios Nikolaos-Korakas Geopark", recently published by the Municipality of Neapolis Vion, the author interprets the findings as fossilized Rhizopalmoxylon $s p$. palm trees, which have undergone a complicate, not fully clarified, fossilization process. Recently, Sakellariou et al. (2007) proposed a fairly different interpretation according to which these structures are fossil carbonate chimneys associated with non-volcanic gas seeping.

In this paper we describe the geological and tectonic setting of the outcrops of Agia Marina, Korakas and Vourlopo of Neapolis region (Fig. 1), we examine the geometrical, structural, sedimentological, geochemical and mineralogical characteristics of these structures and we draw some conclusions attempting to clarify their nature and origin.

\section{Geological Setting}

The alpine basement of Neapolis-Maleas Peninsula is mainly composed of Tripolis unit limestones and metamorphics of the Arna unit. Thin- to thick-bedded Jurassic limestones and thick- 
bedded, Upper Triassic limestones to dolomites form the mountainous parts of the peninsula. They tectonically overlay clastic, carbonate and volcanic rocks of the Tyros beds and the metamorphic rocks (metaclastites, thin marbles and metavolcanites) of Phyllites-Quartzites (Arna) unit (Gerolymatos, 1999).

Upper Pliocene(?) - Lower Pleistocene fluvio-terrestrial deposits as well as marine and lacustrine pelites, sandstones, conglomerates and carbonate rocks occur in the morphologically lower and the coastal parts of the peninsula. The Quaternary deposits may be as thick as 250-300m and cover unconformably the alpine basement. They alternate rapidly, both horizontally and vertically and commonly contain layers of terrestrial origin (Gerolymatos, 1999). All three study areas presented in this paper fall into the marine deposits of this formation.

\section{Field Results}

\subsection{Agia Marina}

The site of Agia Marina (Lat.: $36^{\circ} 26.405^{\prime}$, Long.: $23^{\circ} 08.556^{\prime}$ ) is located on the south-facing coastline of Maleas Peninsula, 5km west of Cape Maleas (Fig. 1). Marine mud/sandstone of Pliocene(?)Pleistocene age (Kowalczyk et al., 1992; Gerolymatos, 1999) outcrop along the coast of the Agia Marina bay. The bedding planes of this clastic formation dip gently to the south. Limestone or dolomite pebbles and rock fragments, $<10 \mathrm{~cm}$ big, occur sporadically, embedded within the $\mathrm{mud} / \mathrm{sandstone}$ formation. The fauna observed and identified in the mud/sandstone of Agia Marina includes Pecten, Chlamys, Ostrea, Balanus, Echinoids, benthonic Foraminifera, Ostracods and Bryozoans (Georgiades-Dikeoulia et al., 2000).

The marine mud/sandstones are unconformably overlain by a thin conglomerate layer (Fig. 2A). The roof of the mud/sandstone truncates their bedding planes, displays irregular morphology and indicates emergence in subaerial condition and subsequent erosion. The erosional unconformity is followed by the deposition of the $<1 \mathrm{~m}$ thick transgression conglomerate, which is composed mainly of, rounded or angular, limestone or dolomite pebbles derived from the adjacent Tripolis unit TriassicJurassic carbonate formations. The deposition of the conglomerate is followed conformably by the formation of a bioclastic limestone of presumably Pleistocene age (Kowalczyk et al., 1992), which forms a well preserved marine terrace.

The entire stratigraphic sequence of the (Plio-)Pleistocene formations (mud/sandstones, transgression conglomerate, bioclastic limestone) of Agia Marina is densely fractured by two systems of vertical to subvertical diaclases (Fig. 2B, 2C). The first system trends NE-SW (N30-60E) and dips with $80^{\circ}-85^{\circ}$ towards N120-150E while the second one trends E-W (N80-110E) and dips with $80^{\circ}-85^{\circ}$ towards N170-200E. The diaclases of both systems are sealed with light grey carbonate material, composed predominantly of calcite. Exposed diaclase-planes are characterised by the presence of dense network of carbonate, mm-to-cm thick veins (Fig. 2D). Some of the diaclases display evidence of small, right-lateral, horizontal displacement.

The spectacular micro-landscape of the Agia Marina site owes its unique character to the presence of column-like, up to $2.5 \mathrm{~m}$ high and $1 \mathrm{~m}$ wide structures, which stand upright (Fig. 3A, 3B) on flat morphological terraces, developed parallel to the bedding planes of the mud/sandstones and the bioclastic limestones or protrude through them. Inspection at shallow depths of the Agia Marina bay by divers revealed similar structures rising through the recent sand deposits or standing on the rocky (sandstone) seafloor (Fig. 3D). They display a wide range of morphological types: cylindrical, conical, mushroom-like and mounded (Fig. 3A to 3E). 

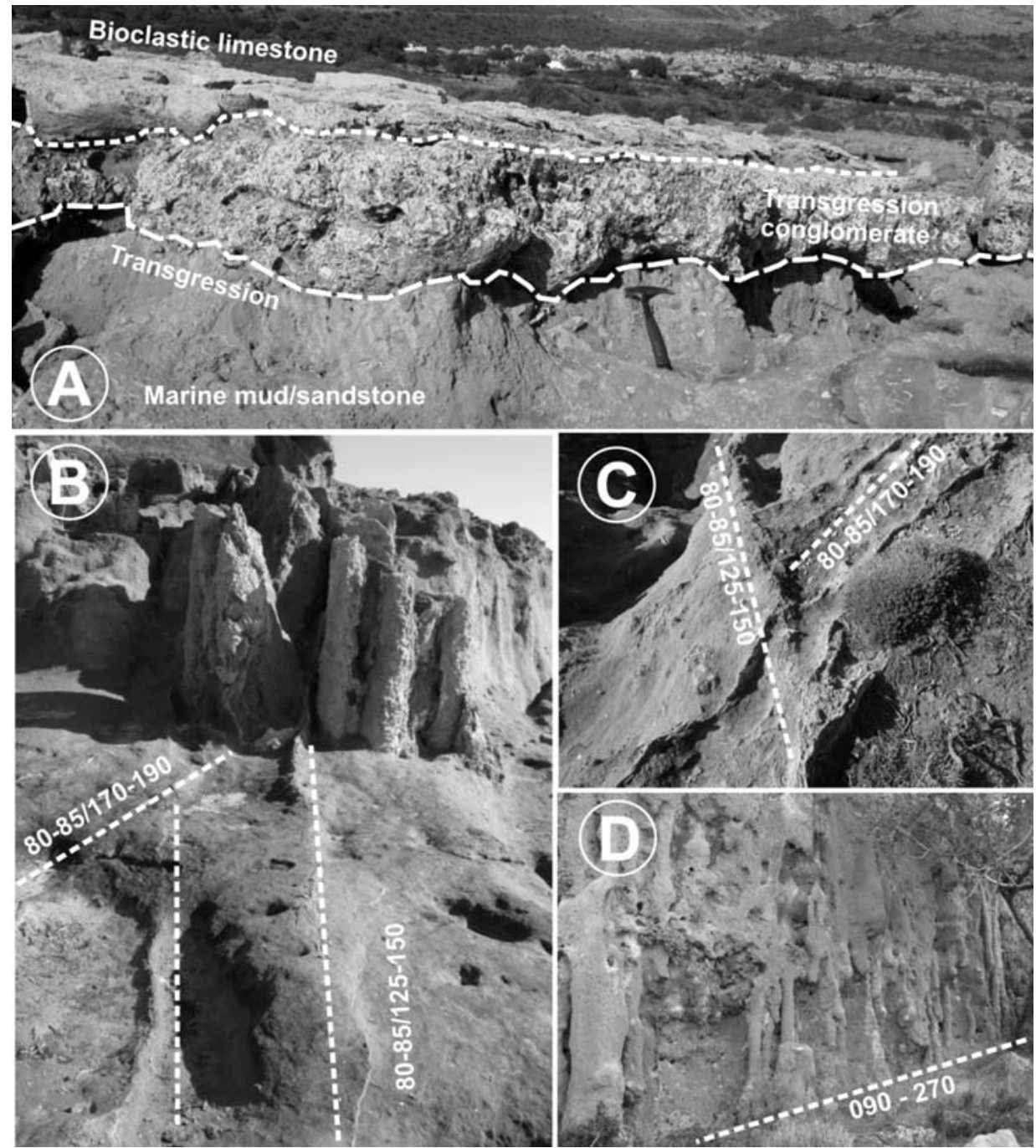

Fig. 2A: The stratigraphic sequence of Agia Marina site.

Fig. 2B - 2D: The two systems of diaclases / fractures in Agia Marina.

They are composed of hard but weathered several $\mathrm{cm}$ thick, whitish, carbonate tube. Their orifice is filled up with dark grey, mud/sandstone material, similar to the surrounding host rock, but with numerous whitish, mm-thin, carbonate veins (Fig. 3E and Fig. 6). The chimney-like structures are rooted in stratigraphically lower levels of the Plio-Pleistocene mud/sandstones and penetrate the overlying carbonate terrace formation (Fig. 3F). Their estimated/visible minimum height may exceed $5 \mathrm{~m}$, but there is no secure evidence how deep they go into the mud/sandstone.

From the fieldwork and the field observations in the site of Agia Marina it became obvious that there is a close relationship between the presence of the diaclase systems and the spatial occurrence of the chimney-like structures. Most, if not all of them, are associated with the diaclases, while the biggest ones are always located on the intersection of two diaclases/fractures. 

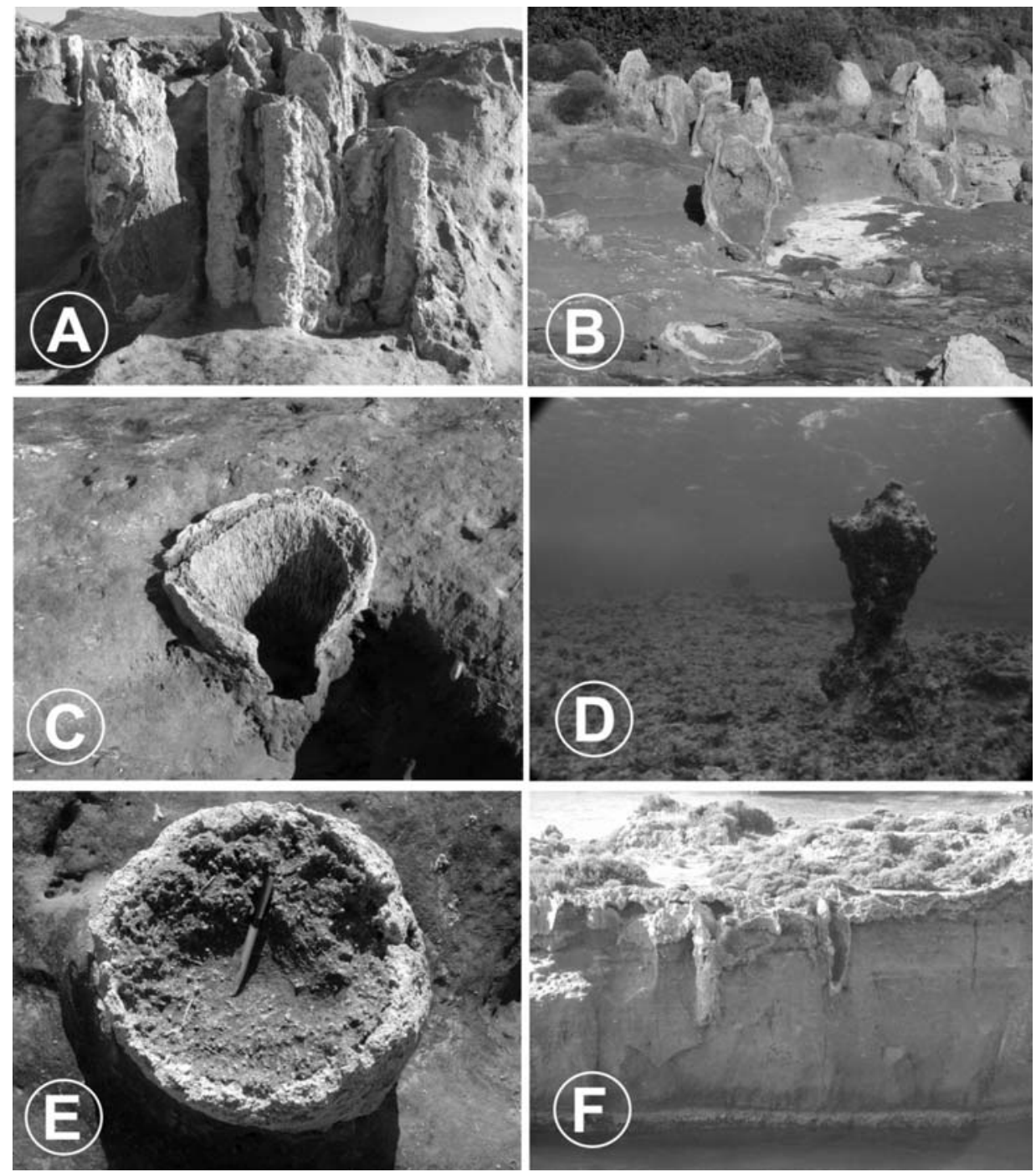

Fig.3A-3F: Collection of photos showing the chimney-like structures of Agia Marina. See text for explanations.

Taking into consideration that the sealing of the diaclases is identical with the material which forms the tubes of these structures, it becomes evident that there is a kind of genetical relationship between them and the formation of the carbonate crusts. The fact that these structures have been observed only in areas crosscut by the diaclases network supports this hypothesis.

We suggest that the carbonate structures, along with the formation of the carbonate sealing of the diaclases resulted from the precipitation of carbonate material due to flow of upward migrating fluids occurred after the diagenesis and lithification of the Plio(?)-Pleistocene sediments. This process is similar to the formation of carbonate chimneys, commonly associated with mud volcanism, observed and studied at numerous sites and various depths on the present day seafloor of the world's oceans where active cold seeping, mainly of biogenic methane, occurs. 

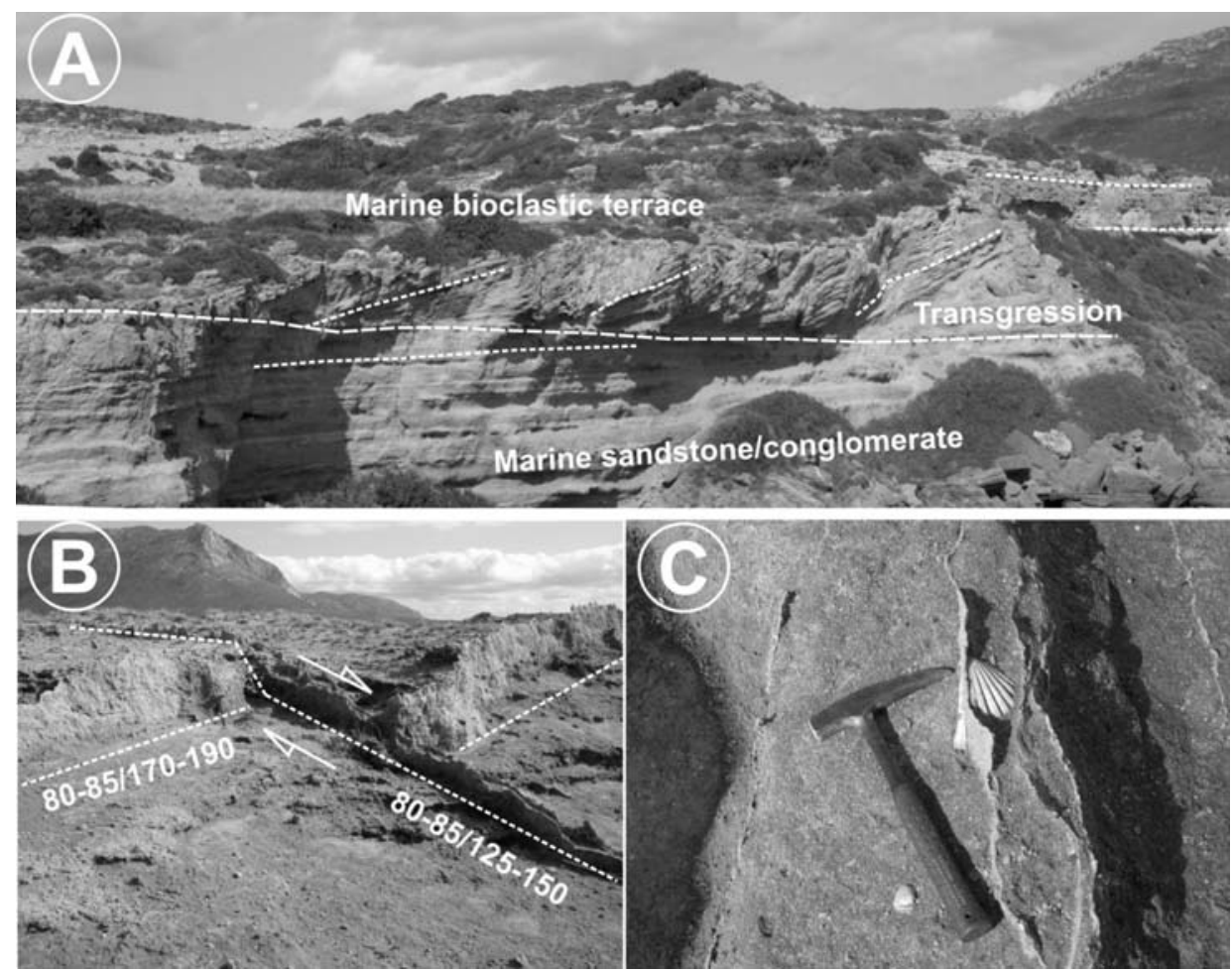

Fig. 4: A. The stratigraphic sequence of Korakas site. B. The two systems of diaclases / fractures in Korakas with evident right lateral displacement. C. Large Pecten intersected by a carbonate-sealed diaclase.

\subsection{Korakas}

The study site of Korakas (Lat.: $36^{\circ} 26.268^{\prime}$, Long.: $23^{\circ} 05.753^{\prime}$ ) is located on the south-facing coastline of Maleas Peninsula, few hundreds $m$ east of the small Korakas village (Fig. 1). Marine sandstone and fine, multicoloured, polymictic conglomerate of Pliocene(?)-Pleistocene age (Kowalczyk et al., 1992; Gerolymatos, 1999) outcrop on the small, rounded peninsula. The bedding planes dip gently to the south, while limestone, dolomite and metamorphic pebbles and rock fragments, $<10 \mathrm{~cm}$ big, occur sporadically, embedded within the fine conglomerate. The fauna observed and identified in Korakas is similar to the one mentioned earlier from the Agia Marina site. The bedding of the fine conglomerates of Korakas is truncated by a planar surface with paleosoil remains and evidence of emergence and erosion. This surface is covered by prograding clastic deposits with sigmoidal bedding which passes upwards to horizontally bedded marine terrace deposits of presumably Pleistocene age (Kowalczyk et al., 1992) (Fig. 4A).

The fine conglomerates of the Korakas study site are densely fractured by two systems of vertical to subvertical, diaclases (Fig. 4B). Like the diaclases of Agia Marina, the first system trends NE-SW (N30-60E) and dips with $80^{\circ}-85^{\circ}$ towards N120-150E while the second one trends E-W (N80-110E) and dips with $80^{\circ}-85^{\circ}$ towards N170-200E. The diaclases of both systems are sealed with carbonate material, which due to its resistance to the erosion, forms very impressive linear ridges similar to massive volcanic dikes. Significant right lateral displacement $(>1 \mathrm{~m})$ has been observed along the diaclases of the first system (Fig. 4B). It is important to mention that the diaclases occur only along specific zones and do not crosscut the entire formation of Korakas. 

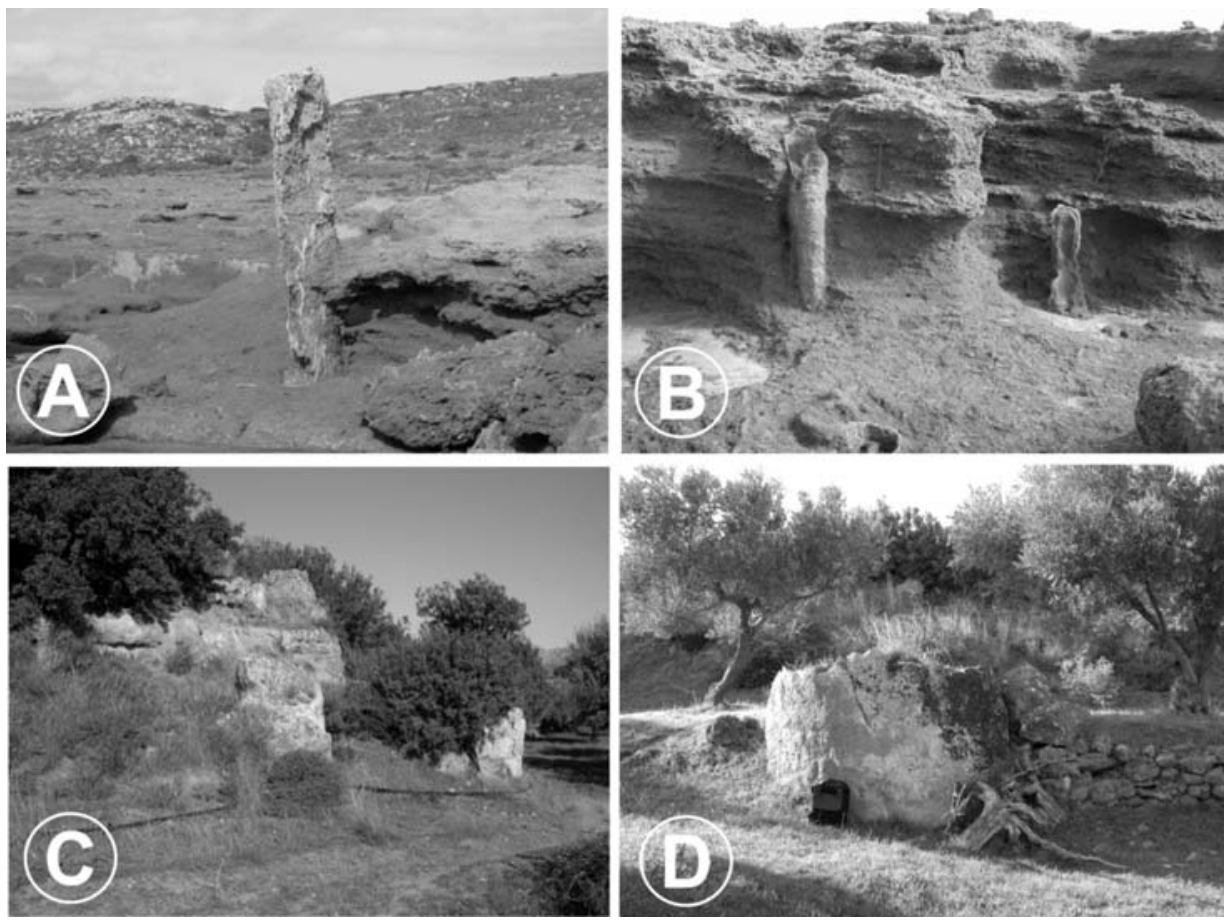

Fig. 5: A - B. Cylindrical chimneys protruding through the fine conglomerates of Korakas. C - D. Huge carbonate chimneys in Vourlopo. See text for explanations.

Column-like, upright standing, mainly cylindrical structures occur in the small rounded peninsula southeast of the small Korakas bay, but not as widespread as in Agia Marina (Fig. 5A \& B). They penetrate the gently dipping bedding planes of the fine conglomerates or rise above the surface. The highest structure observed in Korakas exceeds $4 \mathrm{~m}$ in height (Fig. 5A). Like in Agia Marina, these structures are composed of hard, few $\mathrm{cm}$ thick, whitish, carbonate tube. The orifice of the cylindrical structures in Korakas is filled up with multicoloured, polymictic, fine conglomerate, similar to the surrounding sedimentary formation, and is penetrated by whitish, mm-thin, carbonate veins.

The development and spatial distribution of chimney-like structures is closely related to the occurrence of the two diaclase systems. They are always located on and along the diaclases, while the biggest, $4 \mathrm{~m}$ high, structure has been formed at the intersection of two diaclases/fractures. It is note worthy, that the chimney-like structures have been observed only in areas crosscut by diaclases.

The above observations from Korakas are very compatible with the ones described earlier for the Agia Marina site. We therefore suggest that the precipitation of carbonate material along the diaclases and the formation of the chimney-like structures took place contemporaneously as results of the same process. In analogy to the Agia Marina site, we interpret the Korakas structures as carbonate chimneys developed at sites of enhanced fluid (methane?) flow, which used the existing diaclases network as conduits for their upward migration. The photo of Fig. $4 \mathrm{C}$ shows a large Pecten crosscut by a sealed diaclase, a fact which clearly indicates that the formation of the diaclases and the carbonate precipitation postdates the deposition of the sediments and possibly their diagenesis / lithification. Consequently, the formation of the chimneys postdates the deposition and diagenesis of the (Plio?-)Pleistocene clastic formation of Korakas. 

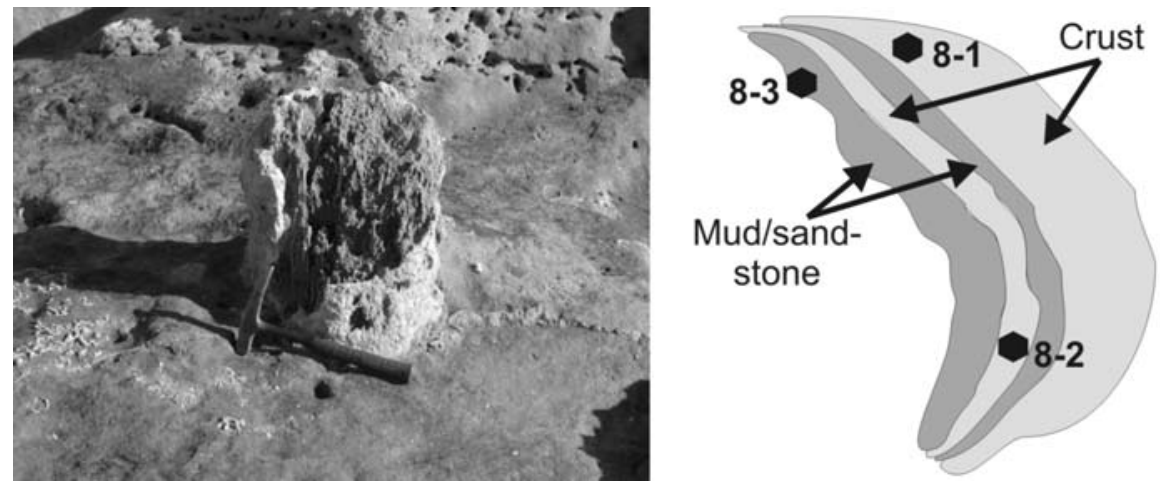

Fig. 6: A small piece of the chimney (shown on the left) was sampled for laboratory analyses (sample 8). The scheme to the right shows the sub-sampling strategy.

\subsection{Vourlopo}

The site of Vourlopo (Lat.: $36^{\circ} 31.592^{\prime}$, Long.: $23^{\circ} 03.472^{\prime}$ ) is located about $2 \mathrm{~km}$ north of the town of Neapolis, on the east-facing slope of a low hill (Fig. 1) and falls into the Plio(?)-Pleistocene marine formation (Kowalczyk et al., 1992; Gerolymatos, 1999). Although the landscape has been altered by agriculture activities, it is evident that like in Agia Marina, marine mud/sandstone constitutes the prevailing sedimentary formation of Vourlopo site. A N-S trending, E-dipping, apparently normal fault displaces the sedimentary formation and forms a steep, 2-5m high scarp along the eastern flank of the hill (Fig. 5C).

Huge, cylindrical, 3-4m wide, column-like structures rise up to $1-1.5 \mathrm{~m}$ from the ground (Fig. 5D). They occur along a zone roughly parallel to the fault scarp or at a small distance $(<10-15 \mathrm{~m})$ from it. Despite their large dimensions, they are similar to the Agia Marina and Korakas structures. The outer tube is made of hard, whitish, carbonate crust and their orifice is filled up with dark grey, mud/sandstone penetrated by numerous whitish, mm-thin, carbonate veins.

In the description of the Agia Marina and Korakas sites it was mentioned that the chimney-like structures are associated with a network of diaclases. The landscape of the site in Vourlopo is either altered due to agriculture activities or covered by dense bushes. Nevertheless, remains of the carbonate sealing of diaclases are preserved on the outer tube surface of some of the cylindrical structures.

\section{Analytic Results}

Samples were taken from the least weathered structures and from vertical veins formed on the planes of the diaclases/fractures of Agia Marina site. The bulk mineralogy was determined using X-ray diffraction (XRD) on powdered samples. The chemical bulk rock composition and major and trace elements were analysed by X-ray fluorescence (Table 1). We present here the results of the analyses of two samples: Sample 5 was taken from the veins developed on the vertical fracture shown in Fig. 2D. Samples 8-1, 8-2 and 8-3 are taken from the chimney-like structure of Fig. 6. The samples 8-1 and 8-2 were taken from the tube while 8-3 from the infill of the orifice.

The thin vein (sample 5) displays carbonate composition $(90 \% \mathrm{CaO})$ with calcite as the dominant mineral. The tube (samples 8-1, 8-2) of the chimney-like structure is mainly composed of calcite (80\% $\mathrm{CaO}$ ) with subordinate quartz $\left(10 \% \mathrm{SiO}_{2}\right)$, while the significantly weathered fill of the orifices (sample 8-3) displays siliceous composition $\left(52 \% \mathrm{SiO}_{2}, 30 \% \mathrm{CaO}\right)$ and muddy character. 
Table 1. Major Elements

\begin{tabular}{|l|c|c|c|c|c|c|c|c|c|c|}
\hline Sample & $\begin{array}{c}\mathrm{SiO}_{2} \\
(\%)\end{array}$ & $\begin{array}{c}\mathrm{Al}_{2} \mathrm{O}_{3} \\
(\%)\end{array}$ & $\begin{array}{c}\mathrm{TiO}_{2} \\
(\%)\end{array}$ & $\begin{array}{c}\mathrm{Fe}_{2} \mathrm{O}_{3} \\
(\%)\end{array}$ & $\begin{array}{c}\mathrm{K}_{2} \mathrm{O} \\
(\%)\end{array}$ & $\begin{array}{c}\mathrm{Na}_{2} \mathrm{O} \\
(\%)\end{array}$ & $\begin{array}{c}\mathrm{CaO} \\
(\%)\end{array}$ & $\begin{array}{c}\mathrm{MgO} \\
(\%)\end{array}$ & $\begin{array}{c}\mathrm{P}_{2} \mathrm{O}_{5} \\
(\%)\end{array}$ & $\begin{array}{c}\mathrm{MnO} \\
(\%)\end{array}$ \\
\hline 5 & 1,82 & 0,81 & 0,023 & 0,13 & 0,057 & 0,992 & 52,57 & 1,627 & 0,0110 & 0,004 \\
\hline $8-1$ & 5,89 & 1,13 & 0,056 & 0,37 & 0,143 & 2,179 & 48,03 & 2,094 & 0,0140 & 0,005 \\
\hline $8-2$ & 18,94 & 2,68 & 0,168 & 1,14 & 0,292 & 1,995 & 39,00 & 2,342 & 0,0209 & 0,014 \\
\hline $8-3$ & 40,68 & 4,94 & 0,357 & 2,34 & 0,577 & 2,078 & 23,69 & 2,728 & 0,0215 & 0,019 \\
\hline
\end{tabular}

\section{Discussion - Conclusions}

The field observations, structural measurements and sedimentological data from the Agia Marina, Korakas and Vourlopo sites of Neapolis region along with the results of the mineralogical and geochemical analyses presented here lead to the conclusion that the structures, previously interpreted as giant sponges or as petrified palm trees, are fossil, carbonate chimneys of non-volcanic origin, associated with cold seeps. Very similar, column-like structures have been found in Eocene sandstones on the Moesian Platform in the area of Pobiti Kamani, close to Varna, Bulgaria, and have been interpreted on the base of sedimentological and geochemical data as carbonate chimneys related to ancient hydrocarbon seepage (De Boever et al., 2006).

The arguments which support this interpretation are the following: (1) they occur in a marine environment, as indicated from the nature of the host sedimentary formation, which is unlike to have favoured the growth of a forest, (2) they are spatially and genetically associated with a dense network of diaclases/fractures, a relationship not necessary for the distribution of sponges or trees (3) their tubes have calcite composition, like the sealing material of the diaclases/fractures, which is unlike for the fossilisation of trees (4) their orifice is filled up with sedimentary material (sandstone or fine conglomerate) similar to the surrounding host formation, a very unlike composition either for fossil sponges or petrified trees (5) they penetrate through the stratigraphic layers, including the erosional unconformity and transgression surface in Agia Marina, (6) they have been formed after the deposition and the diagenesis of the host sedimentary formation.

Cold seeps in modern marine seafloor environments are associated with a variety of gas releasing processes, such as mud volcanoes and mud flows, gas chimneys, pockmarks, authigenic carbonate precipitation etc (Hovland \& Judd, 1988). Actively venting carbonate chimneys and crusts are forming at sites of gas expulsion due to bacterially mediated carbonate precipitation. They have been discovered and studied in many places in the world, including the Gulf of Cadiz (Diaz-del-Rio et al., 2003), the East Mediterranean Ridge (Kopf et al., 2001), the Nile deep-sea fan (Loncke et al., 2004), the Anaximander Mountains (Lykousis et al., 2005) and other places in the Mediterranean and the Black Sea (Mascle et al., 2006 and references therein). They display morphological characteristics very similar to the ones described here from Agia Marina and Korakas. Their occurrence and formation is associated with fluid flow (predominantly methane) and with liquefied mud flow from deeper layers to the seafloor. The upward migration of the fluids takes place along the existing tectonic elements which serve as conduits.

The chimneys of Agia Marina, Korakas and Vourlopo, described here, are associated with a dense network of diaclases and/or fractures, which crosscut the marine Plio(?)-Pleistocene formations of Neapolis region. The diaclases/fractures occur only locally, along narrow zones and do not affect the entire sedimentary sequence. We suggest that the zones of dense diaclases/fractures represent zones of lateral displacement developed after the deposition of the Plio(?)-Pleistocene marine sequence of Neapo- 
lis region. The tectonic stresses within these zones resulted in building up the necessary overpressure which initiated the upward migration of fluids, like methane, and gave birth to the precipitation of calcite along the fractures and the formation of the chimneys within the sedimentary sequence.

\section{Acknowledgments}

We would like to thank our colleague Kostas Katsaros for the inspection of the shallow seafloor and the underwater photos. We are grateful to Mr. Ioannis Kousoulis, Mayor of Neapolis, for his hospitality during our visit in the region.

\section{References}

De Boever, E., Swennen, R. and Dimitrov, 1., 2006. Lower Eocene carbonate cemented chimneys (Varna, NE Bulgaria): Formation mechanisms and the (a) biological mediation of chimney growth? Sedimentary Geology 185, 159-173.

Diaz-del-Rio, V., Somoza, L., Martinez-Frias, J., Mata, M.P., Delgado, A., Hernandez-Molina, F.J., Lunar, R., Martin-Rubi, J.A., Maestro, A., Fernandez-Puga, M.C., Leon, R., Llave, E., Medialdea, T., Vazquez, J.T., 2003. Vast fields of hydrocarbon-derived carbonate chimneys related to the accretionary wedge/olistostrome of the Gulf of Cadiz. Marine Geology, 195, 177-200.

Georgiades-Dikeoulia, E., Symeonides, N. \& Giannopoulos V., 2000. A unique outcrop of large-size sponges in the SE Peloponnesus (Lakonia district). Geol. Soc. Greece, Sp. Publ, No 9, 95-100.

Hovland, M., \& Judd, A. G. 1988. Seabed pockmarks and seepages: Impact on geology, biology and the marine environment. London: Graham and Trotman, 293 p.

Gerolymatos, I., 1999. Geological Map of Greece, scale 1:50.000, Neapolis - Ag. Nikolaos Sheet IGME 1999.

Kopf, A., Klaeschen, D., Mascle, J. 2001. Extreme efficiency of mud volcanism in dewatering accretionary prisms. Earth and Planetary Science Letters, 189, 295-313.

Kowalczyk, G. \& Winter K-P., 1991. Roehren- und saeulenfoermige Strukturen in jungen Sedimenten Suedost-Lakoniens (Peloponnes, Griechenland). Geol. Inst. Univ. Koeln, Sonderveroeffentlichungen No 82, 423-431.

Kowalczyk, G., Winter, K-P., Steinich, G. \& Reisch, L., 1992. Jungpleistozaene Strandterrassen in Suedost-Lakonien (Peloponnes, Griechenland). Schriftenr. F. Geowiss., 1(1), 1-72, Berlin.

Lekkas, S., Alexopoulos, A. and Danamos, G., 1995. Neotectonic map of Greece, 1 :100. 000, GythioNeapolis sheet. Publ. by: European Centre on Prevention and Forecasting of Earthquakes, Earthquake Planning and Protection Organization, Tectonic Committee of the Geological Society of Greece, Athens.

Loncke,L., Mascle, J., Fanil Scientific Parties, 2004. Mud volcanoes, gas chimneys, pockmarks and mounds in the Nile deep-sea fan (Eastern Mediterranean): geophysical evidences. Marine Geology 21, 669-689.

Lykousis, V., Alexandri, S., Woodside, J., Nomikou, P., Perissoratis, C., Sakellariou, D., de Lange, G., Dahlmann, A., Casas, D., Rousakis, G., Ballas, D. \& Ioakim, Ch., 2005. New evidence of extensive active mud volcanism in the Anaximander mountains (Eastern Mediterranean): The "ATHINA" mud volcano. Environmental Geology 46:1030-1037.

Mascle, J., Sakellariou, D., and participants of the $29^{\text {th }}$ CIESM Workshop, 2006. Executive Summary. In: CIESM Workshop Monographs 29, 2006, Fluid seepages / mud volcanism in the Mediterranean and adjacent domains.

Sakellariou, D., Fountoulis, I. and Lykousis, V., 2007. Fossil carbonate chimneys discovered in Lower Pleistocene marine sediments of Southern Peloponnese, Greece. In: Proceedings $38^{\text {th }}$ CIESM, Congress, 9-13 April 2007, Istanbul. 